\title{
Bioethanol production from rice
} straw by simultaneous saccharification and fermentation with statistical optimized cellulase cocktail and fermenting fungus

\author{
Maki Takano and Kazuhiro Hoshino*
}

\begin{abstract}
Background: Rice straw is one of the abundant lignocellulosic biomass with potential as a feedstock for bioethanol production. To produce ethanol from the biomass biologically, enzymatic hydrolysis is necessary that can effectively degrade rice straw into fermentable sugars such as glucose and xylose. Many researches utilized many kinds of commercial cellulase reagents on the hydrolysis of cellulose. Since these have different enzyme activities, enzyme reagents suitable for each biomass must be selected. In this study, three appropriate cellulase reagents were selected by multivariate analysis technique and then optimized by design of experiments method for efficient hydrolysis of alkali-pretreated rice straw. Moreover, an ethanol production from the treated straw was performed by simultaneous saccharification and fermentation (SSF) with the optimized enzyme cocktail and xylose-fermenting fungus of Mucor circinelloides.
\end{abstract}

Results: Pretreatment by alkali solution of rice straw resulted in the increase of fermentable sugar content from 56.3 to $80.0 \%$. The desirable commercial enzyme reagents for saccharification of the straw were determined as a combination of "Cellulase Onozuka 3S", "Cellulase TAmano 4", and "Pectinase G Amano" by a multivariate analysis based on various cellulolytic activities of each reagent. The optimum mixing ratio was calculated by response surface method based on design of experiment method. The optimized cocktail successfully achieved $75.3 \mathrm{~g} / \mathrm{L}$ in production of the total fermentable sugar by hydrolysis of alkali-treated rice straw that agreed with the hydrolysis efficiency of $94.1 \%$. SSF of $100 \mathrm{~g} / \mathrm{L}$ treated rice straw with the optimal cocktail and M. circinelloides under aerobic condition resulted in $30.5 \mathrm{~g} / \mathrm{L}$ ethanol concentration for $36 \mathrm{~h}$.

Conclusion: The construction of cellulase cocktail by the proposed statistical method enabled efficient hydrolysis of alkali-treated rice straw. SSF process combining the optimized cocktail and a xylose-fermenting fungus could be expected as a promising system for ethanol production from various lignocellulosic biomasses.

Keywords: Ethanol, Rice straw, Hydrolysis enzyme, Multivariate analysis, Mucor

\section{Background}

Bioethanol produced from lignocellulosic biomass is kept attracting global attention as alternative energy for oil fuel for sustainable energy society, since depletion of fossil fuel, global warming, and reduction of natural

\footnotetext{
*Correspondence: khoshino@eng.u-toyama.ac.jp

Graduate School of Science and Engineering, University of Toyama, 3190 Gofuku, Toyama 930-8555, Japan
}

resources has been increased concern (Chandra et al. 2012). Lignocellulosic biomass is arises from agricultural, forestry, and industrial waste. Rice straw is one of the agricultural waste caused from rice cropping and is a hopeful feedstock for bioethanol production, because cellulose and hemicellulose content is more than $50 \%$. Although there are many researches about ethanol production from rice straw (Binod et al. 2010), manufacture process of the ethanol has not been realized yet because 
of high cost for collection and preservation from rice field ridge, fine-powderization and dissolution, fermentation system, etc. Development of effective ethanol production system from abundant biomass such as rice straw is an urgent necessity for novel energy supply.

Rice straw has heterogeneous complex structure in which hard cellulose fiber due to the crystal structure and entangled lignin and hemicellulose is contained. In the bioconversion to ethanol from lignocellulose, pretreatment by physical and/or chemical method is necessary to break the strong structure and obtain fermentable sugars easily by biocatalyst such as cellulase, xylanase, ligninase, etc. Many researches have performed physical and chemical processing for pretreatment of lignocelluloses (Binod et al. 2010). The physical treatment includes steaming (Wang et al. 2011), steam explosion (Liu et al. 2014 and Sasaki et al. 2012), grinding and milling (Jin and Chen 2006), and irradiation (Marx et al. 2014). The chemical treatment includes alkali (Gáspár et al. 2007), acid (Nair et al. 2017), and ammonia treatment (Kim and Lee 2007). Especially, among the chemical treatments, alkali treatments using $\mathrm{NaOH}, \mathrm{KOH}, \mathrm{CaOH}$, and $\mathrm{Na}_{2} \mathrm{CO}_{3}$ are more effective than other chemical treatments, because it is able to break the ester bonds between lignin, hemicellulose, and cellulose, so that lignin and a part of hemicellulose are concurrently removed (Gáspár et al. 2007; Khaleghian et al. 2015). Moreover, the pretreatment was able to reduce excessive degradation to furfural, 5-HMF, and vanillin more than acid treatment. These reactions result in cellulose fiber swelling and improve of cellulase contact to the fiber. After pretreatment, biomass requires enzymatic hydrolysis on bioethanol production process. There are many kinds of hydrolysis enzyme reagent worldwide and any pretreated biomass demand the own reagents suitable for effective hydrolysis. However, few researches have performed both selection of the reagents and determination of the mixing ratio statistically, whereas hydrolysis conditions have been mentioned by statistical optimization method (Singh and Bishnoi 2012). The selection of appropriate cellulase is very difficult because of structural difference of each biomass and difference of enzymatic activities in commercial cellulase reagents.

The fungus Mucor circinelloides J used in this study is a mutant constructed by carbon ion-beam irradiation to improve xylose fermentation. Mucor sp. of parental strain is known as ethanol-producing fungus which is able to ferment not only glucose but also xylose and other monosaccharides included $N$-acetyl glucosamine (Millati et al. 2005; Takano and Hoshino 2012; Inokuma et al. 2013). Moreover, it was characterized the ability to grow and ferment simultaneously under aerobic and anaerobic conditions. As lignocellulosic biomass such as rice straw contains a great deal of xylose, use of xylose-fermenting microorganism is necessary to achieve efficient ethanol production from such materials. The strain is also able to slightly secrete cellulase (endo- $\beta$-glucanase, cellobiohydrolase, $\beta$-glucosidase) and xylanase (endo- $\beta$-xylanase, $\beta$-xylosidase) (Kato et al. 2013) and directly grow on polysaccharides. Furthermore, it has tolerance for fermentation inhibitors such as furfural and 5-HMF produced by pretreatment with high temperature and pressure.

In this study, ethanol production was investigated by performing simultaneous saccharification and fermentation (SSF) of rice straw pretreated by alkali with thermal method. To hydrolyze the substrate to fermentable sugar in the process, some desirable commercial enzyme reagents were selected based on regression analysis using enzymatic activities, and then, mixing ratio of them was optimized the design of experiments (DOE) with response surface method (RSM). The optimized enzyme cocktail was used in bioconversion of alkali-treated rice straw to fermentable sugar and subsequent ethanol by SSF system with $M$. circinelloides.

\section{Methods}

\section{Rice straw}

Rice straw was obtained from a high-yielding rice harvested at Nanto-city of Toyama in Japan. It was air-dried, cut in about $2 \mathrm{~cm}$ with scissors, and pulverized using a BLENDER 7011HB (WARING COMMERCIAL, USA) prior to pretreatment. Components in rice straw that are cellulose, hemicellulose, lignin, acid-soluble lignin, and ash were assayed by Klason lignin method (López et al. 2010).

\section{Commercial enzyme reagents}

Hydrolysis of rice straw was carried out with commercial food-processing cellulase reagents. The reagents were of 15 kinds as follows; Meicelase (Meiji Seika Pharma, Japan), Cellulase T "Amano 4", Cellulase A "Amano 3", Pectinase G "Amano", Hemicellulase "Amano 90" (Amano Enzyme, Japan), Cellulase Y-NG, Cellulase "Onozuka 3S", Cellulase "Onozuka R-10" (Yakult Pharmaceutical Industry, Japan), Sumizyme AC, Sumizyme X, Sumizyme SNX (Shin-Nihon Kagakukogyo, Japan), Cellulase Trichoderma viride and Novozyme 188 (Sigma-Aldrich Co., St Louis, MO), Accellerase $1500^{\circledR}$ (DuPont, DE, USA), and Vecelex (Godo-Shusei, Japan). Protein content of each cellulase was determined by Lowry method (Lowry et al. 1951).

\section{Microorganism for ethanol production}

Mucor circinelloides J was used as a fermenting fungus in this study. The fungus is a mutant of Mucor circinelloides NBRC4572 (Takano and Hoshino 2012; Kato et al. 
2013; Inokuma et al. 2013; Komeda et al. 2014) constructed by carbon ion-beam irradiation (Wakaswan Energy Research Center, Fukui, Japan). Then, it was bred for efficient ethanol production from both glucose and xylose. The mutant was pre-cultured for 3 days at $28{ }^{\circ} \mathrm{C}$ on Difco ${ }^{\mathrm{TM}}$ Potato Dextrose Agar (PDA) plate after inoculation from PDA slant stored at $4{ }^{\circ} \mathrm{C}$.

\section{Pretreatment of rice straw by alkali solution}

Rice straw was soaked in $1 \mathrm{M} \mathrm{NaOH}$ solution at the concentration of 80 g-dry straw/L- $\mathrm{NaOH}(\mathrm{aq})$ overnight at room temperature and then thermally treated by autoclave at $121{ }^{\circ} \mathrm{C}$ for $1 \mathrm{~h}$ (Janker-Obermeier et al. 2012). The treated material was neutralized by $1 \mathrm{M} \mathrm{HCl} \mathrm{solu-}$ tion after cooling and then washed thoroughly by water several times. The washed material was dried in oven at $50{ }^{\circ} \mathrm{C}$ until completely dried and then powdered using a pulverizer (BLENDER $7011 \mathrm{HB}$ ).

\section{Optimization of cellulase reagent}

Some cellulase reagents for effective hydrolysis of alkalitreated rice straw were first selected from 15 kinds of commercial cellulase reagents based on the calculation of regression analysis method on Excel solver, which is one of the multiple classification analysis. The relational expression was estimated by statistical method on explanatory variable and objective variable about hydrolysis efficient by each enzyme. The explanatory variables were derived by enzymatic activities of endo- $\beta$ glucanase (EBG), cellobiohydrolase $(\mathrm{CBH}), \beta$-glucosidase (BGL), xylanase $(\mathrm{XN}), \beta$-xylosidase $(\mathrm{BX})$, Filter paper degradation activity (FPU), and unwoven cellulosic cloth $\left(\mathrm{BEMCOT}^{\circledR}\right)$ degradation activity (BCU). The objective variables (hydrolysis activity) were derived by hydrolysis activities analyzed with $10 \mathrm{~g} / \mathrm{L}$ pretreated straw by each enzyme reagent of $1 \mathrm{~g}$-protein $/ \mathrm{L}$ at $30{ }^{\circ} \mathrm{C}, \mathrm{pH} 5.5$, and $120 \mathrm{rpm}$. The activities were determined as reducingsugar production per $1 \mathrm{~min}$. These enzymatic activities as variables were fed to regression analysis tool in Excel and regression expression was obtained from coefficients in displayed analysis of variance (ANOVA) table containing significant value ( $F$ value), coefficients, and probability value ( $P$ value), etc. Three kinds of reagents were selected based on the high coefficients of activity in the expression. Next, an optimum ratio of these reagents mixture was constructed by design of experiments (DOE) method using Design-Expart ${ }^{\circledR}$ 8. The software planned 14 kinds of mixing pattern that was necessary experiments for calculation of optimum ratio using the central composite design. Hydrolysis reactions were performed using these mixtures of enzyme reagents on the basis of the designed patterns with $100 \mathrm{~g} / \mathrm{L}$ alkali-treated rice straw for $48 \mathrm{~h}$. After the reactions, hydrolysates were separated by filtration (Filter paper No. 131, Advantec Ltd., Japan) and the liquids were analyzed by HPLC about the concentrations of glucose and xylose. Then, these sugar concentrations were input to the software again and that resulted in drawing a response surface of desirability on fermentable sugar production from pretreated straw and simultaneously the software calculated candidate of optimum mixing ratio of reagents by ANOVA.

\section{Enzymatic hydrolysis of rice straw}

Hydrolysis reactions were performed in $100 \mathrm{~mL}$ bottles containing $100 \mathrm{~g} / \mathrm{L}$ of the pretreated rice straw suspended in $25 \mathrm{~mL}$ of $0.1 \mathrm{M}$ sodium acetate buffer ( $\mathrm{pH} 5.5)$ or culture medium. These were previously autoclaved at $121{ }^{\circ} \mathrm{C}$ for $15 \mathrm{~min}$. Reaction was started by addition of the filter-sterilized single or cocktail enzymes at the total protein concentration of $2 \mathrm{~g} / \mathrm{L}$. The pretreated rice straw suspension was incubated at $28{ }^{\circ} \mathrm{C}$ and $120 \mathrm{rpm}$ for $96 \mathrm{~h}$. Hydrolysates were obtained by removal of solid fraction by filtration and its sugar concentration was analyzed by HPLC system.

\section{Simultaneous saccharification and fermentation (SSF)}

SSF experiments were performed in $100 \mathrm{~mL}$ bottle containing $100 \mathrm{~g} / \mathrm{L}$ pretreated rice straw suspension in $25 \mathrm{~mL}$ medium containing yeast extract (Oriental yeast, Tokyo, Japan), $5 \mathrm{~g} / \mathrm{L} ;\left(\mathrm{NH}_{4}\right)_{2} \mathrm{SO}_{4}, 7.5 \mathrm{~g} / \mathrm{L} ; \mathrm{KH}_{2} \mathrm{PO}_{4}, 3.5 \mathrm{~g} / \mathrm{L}$; $\mathrm{MgSO}_{4} \cdot 7 \mathrm{H}_{2} \mathrm{O}, 0.75 \mathrm{~g} / \mathrm{L} ; \mathrm{CaCl}_{2} \cdot 2 \mathrm{H}_{2} \mathrm{O}, 1.0 \mathrm{~g} / \mathrm{L}$ (Wako Pure Chemical Industries, Ltd. Osaka, Japan) and the $\mathrm{pH}$ was adjusted at 5.5. Cultivation was started by inoculating $1 \mathrm{~mL}$ fermenting fungus suspended in normal saline and simultaneously adding the filter-sterilized single of cocktail of cellulase that conditioned at $2 \mathrm{~g}$-protein/L and then shaken at $120 \mathrm{rpm}$ in an incubator at $28{ }^{\circ} \mathrm{C}$ for $96 \mathrm{~h}$. The cultures were filtrated and separated supernatants containing sugars and ethanol produced by SSF were analyzed by HPLC.

\section{Measurement of enzymatic activity}

Enzymatic activity existed in each commercial cellulase reagent about $\mathrm{EBG}, \mathrm{CBH}, \mathrm{BGL}, \mathrm{XN}$, and $\mathrm{BX}$ were measured using Azo-CM-cellulose (Megazyme, Ireland), 4-nitrophenyl- $\beta$-D-cellobioside, 4-nitrophenyl- $\beta$-D-glucopyranoside (Sigma-Aldrich), Azo-arabinoxylan (Megazyme), and 4-nitrophenyl- $\beta$ D-xylopyranoside (Sigma-Aldrich), respectively. EBG and $\mathrm{XN}$ activities were determined by reference to each standard curve followed as protocol. $\mathrm{CBH}, \mathrm{BGL}$, and $\mathrm{BX}$ activities were determined as the ability by which releases $1 \mu \mathrm{mol}$ of 4 -nitrophenol per $1 \mathrm{~min}$. FPU, BCU, and rice straw hydrolysis activities were measured by degradation of filter paper (Whatman ${ }^{\circledR}$ qualitative filter paper, Grade 1, Sigma-Aldrich) and BEMCOT ${ }^{\circledR}$ (Asahi 
Kasei Corporation, Japan), respectively, in acetate buffer (pH 5.5) for $1 \mathrm{~h}$ at $28^{\circ} \mathrm{C}$. Then, produced reducing sugar was analyzed by 3,5-Dinitrosalicylic acid (DNS) method (Breuil and Saddler 1985) and the activities were determined as the ability by which $1 \mu \mathrm{mol}$ of reducing sugar per 1 min released.

\section{Analytical methods}

Klason lignin method was performed with a little modification for componential analysis of rice straw (López et al. 2010). First, $0.3 \mathrm{~g}$ of straw was soaked in $72 \%$ sulfuric acid of $4.5 \mathrm{~mL}$ for $3 \mathrm{~h}$ and then diluted to $3 \%$ by addition of water. Next, the suspension was autoclaved at $121^{\circ} \mathrm{C}$ for $30 \mathrm{~min}$. After cooling, liquid and solid were separated by filtration using glass fiber filter (Advantec Ltd.). Liquid was used for analysis of sugars and the amount of solid was used for determination of lignin content. The content of cellulose in rice straw was determined from the amount of glucose in the liquid phase analyzed by Glucose C II-test Wako (Wako Pure Chemical Industries, Ltd.) after neutralization to $\mathrm{pH}$ 7.0. The hemicellulose content in liquid phase was determined by phenol-sulfuric acid method for total sugar analysis and then calculated by subtracting the amount of the previous glucose amount from the total amount of sugars. Another $0.3 \mathrm{~g}$ straw was used ashing treatment at $500{ }^{\circ} \mathrm{C}$ for $2 \mathrm{~h}$ and then the ash weight was measured. Lignin content was calculated by subtracting the amount of the ash weight from the previous solid weight.

The products such as glucose, xylose, xylitol, glycerol, and ethanol formed by hydrolysis or SSF were determined by HPLC (LC-10AD, Shimadzu Co., Kyoto, Japan) equipped with a refractive index detector (RID-10A, Shimadzu Co.) and ICSep WA-1 Wine Analysis column (Transgenomic, NE, USA) operated at $40{ }^{\circ} \mathrm{C}$ with $1.25 \mathrm{mM}$ sulfuric acid as mobile phase at flow rate of $0.6 \mathrm{~mL} / \mathrm{min}$.

\section{Results and discussion Component of rice straw}

Removal of lignin from biomass by pretreatment is essential to produce ethanol from rice straw efficiently by saccharification and fermentation. Among many kinds of pretreatment method for biomass, alkali pretreatment is profitable method because the treatment is able to remove lignin easily, fiberize, and break the crystal structure of cellulose (Taherzadeh and Karimi 2008). Figure 1 shows the componential ratio of raw rice straw and the alkali-treated straw. Each result of the componential analysis was shown based on the mean value of three times. The pretreatment decreased lignin content from 29.6 to $11.6 \%$ and also reduced inorganic substances as ash containing silica from 14.1 to $8.5 \%$. Since these cover the fiber, the reduction affected not only to increase cellulosic fiber content, but also to be accessible to the fiber for enzymes and fermenting microorganism. Cellulose contents increased to $65.5 \%$ from $32.0 \%$. However, the hemicellulose content decreased from 24.2 to $14.5 \%$ because of partially solubilization of xylan by alkali treatment (Carvalheiro et al. 2008). From these results, the fermentable sugar in the straw increased to $80.0 \%$ from $56.3 \%$ by the pretreatment. Considering total mass balance, cellulose recovery was $79.8 \%$ after the treatment. The treatment achieved production of the reformed material that contains $142 \%$ higher fermentable sugar per unit mass than that of raw rice straw. Therefore, alkali pretreating method was a promising method for well removal of lignin from rice straw and obtainment of the cellulose fiber.

According to other reports, $\mathrm{NaOH}$ treatment to rice straw resulted in multiple cellulose and hemicellulose content by treatment process. A treatment with $5 \%$ $\mathrm{NaOH}$ for $1 \mathrm{~h}$ at $40{ }^{\circ} \mathrm{C}$ and autoclave at $121{ }^{\circ} \mathrm{C}$ for $30 \mathrm{~min}$ increased $171 \%$ of cellulose content and decreased $65.9 \%$ of hemicellulose content (Oberoi et al. 2012). Another treatment with $4 \% \mathrm{H}_{2} \mathrm{SO}_{4}$ at $121{ }^{\circ} \mathrm{C}$ for $60 \mathrm{~min}$, and then, $0.5 \% \mathrm{NaOH}$ at $121{ }^{\circ} \mathrm{C}$ for $30 \mathrm{~min}$ increased $195 \%$ of cellulose content and decreased $89.5 \%$ of hemicellulose content (Narra et al. 2015). In this study, cellulose increase was $205 \%$ and hemicellulose decrease was $40.1 \%$, which were higher climb of cellulose and maintain hemicellulose content than these reports. The treatment in this study suggested great attainment method for them in biomass with moderate loss of hemicellulose, since effective ethanol production requires making best use of these polysaccharides in biomass.

\section{Selection and optimization of hydrolysis enzymes}

Hydrolysis of lignocellulosic biomass requires effect of multiple enzyme activities such as EBG, CBH, BGL, $\mathrm{XN}, \mathrm{BX}, \mathrm{FPU}$, and $\mathrm{BCU}$. The hydrolysis rate of biomass is greatly controlled by the balance of these activities. This study chose commercial enzyme reagents with low price and quality for economical process. These possess particular activities because of the enzyme production origins and methods. Therefore, compounding several enzymes was expected to provide the synergy effect for enhancement of hydrolysis reaction and to cover the deficient activities each other under low dose condition. Figure 2 shows protein contents in these reagents per powder weight and their specific activities related to polysaccharide hydrolysis. Each reagent showed multiple protein contents and activities that act complicatedly on the cellulose and hemicellulose complex in biomass. Cellulase Onozuka 3S and Sumizyme X showed high activity on EBG, Cellulase T, Cellulase Onozuka 3S, and 


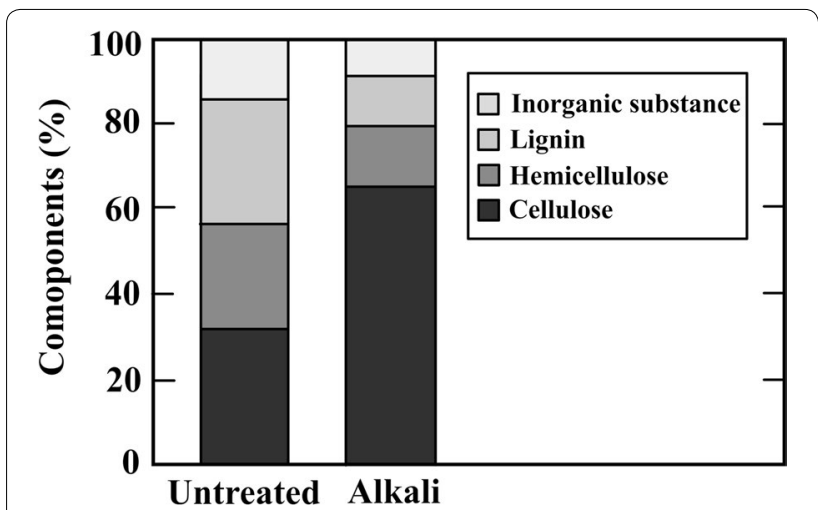

Fig. 1 Components' ratio of raw and alkali-treated rice straw

Sumizyme X on CBH, Meicelase on BGL, Sumizyme AC on XN, and Pectinase G on BX. In addition, Fig. 3 shows hydrolysis activity of alkali-treated rice straw by these reagents. Meicelase, Cellulase T, and Cellulase Onozuka $3 S$ indicated comparatively high degradation activity. However, determination of only one appropriate reagent was difficult for hydrolysis of the straw based on the results of various activities. Blending was desirable by combining the reagents having various enzyme activities for efficient hydrolysis of the rice straw. Therefore, suitable enzyme reagents were selected to combine them based on the multivariate analysis by setting enzymatic activities described in Fig. 2 as explanatory variables and hydrolysis activities in Fig. 3 as objective variable $(Y)$. Regression expression obtained by the analysis was as follows:

$$
\begin{aligned}
Y= & 1.562-2.578(\mathrm{CBH})+1.193(\mathrm{EBG})+1.549(\mathrm{FPU}) \\
& +0.057(\mathrm{XN})+0.305(\mathrm{BCU}) \\
& -0.032(\mathrm{BGL})-0.244(\mathrm{BX}) .
\end{aligned}
$$

The coefficient in the expression showed the weight on degradation of the straw and large absolute value indicated grate requirement. This result is significant as evidenced by Fisher's F test, as the multiple correlation determination $R^{2}=0.725$, and the very low significant value of $F=0.008$. Here, $P$ value indicates the significance probability of the coefficient of each explanatory variable and this value is required to be less than 0.05 which shows variation of less than $5 \%$. Because the $P$ value on $(\mathrm{XN}),(\mathrm{BGL})$, and $(\mathrm{BX})$ in this statistical analysis was 0.87 , 0.59 , and 0.84 , respectively, which were considerably higher than 0.05 , these parameters should involve poorly in the hydrolysis. Another multivariate analysis was performed again except for these three inputs and new regression expression was calculated. As a result, degradation activity was obtained as follows:

$$
\begin{aligned}
Y= & -3.431-2.416(\mathrm{CBH})+1.155(\mathrm{EBG}) \\
& +1.418(\mathrm{FPU})+0.283(\mathrm{BCU}) .
\end{aligned}
$$

The analysis resulted in significant expression with $R^{2}=0.791, F=0.0002$, and $P$ values of explanatory variables CBH, EBG, FPU, and BCU of 0.02, 0.001, 0.00003, and 0.0006 , respectively. The expression confirmed the requirement of these four activities for hydrolysis of the treated straw. From these viewpoints, Cellulase T Amano 4 (denoted by Cellulase T) with high activities of $\mathrm{CBH}$, FPU, and BCU, and Cellulase Onozuka 3S (Onozuka) with high $\mathrm{CBH}, \mathrm{EBG}$, and $\mathrm{BCU}$ were chosen as candidates for preparing a cocktail. In addition, Pectinase $\mathrm{G}$ Amano (Pectinase G) was selected for hemicellulose degradation activities of $\mathrm{XN}$ and $\mathrm{BX}$, since hemicellulose was still contained in the alkali-treated rice straw. The suggested analysis method can offer accurate response for selection of appropriate agents from various reagents for hydrolysis of any biomass or even any different pretreated substances from the same material. Since there are many excellent reagents of commercial enzyme around the world, selection of appropriate one from them is complicated issue for effective hydrolysis of any substrate. Construction of database previously on enzymatic activities

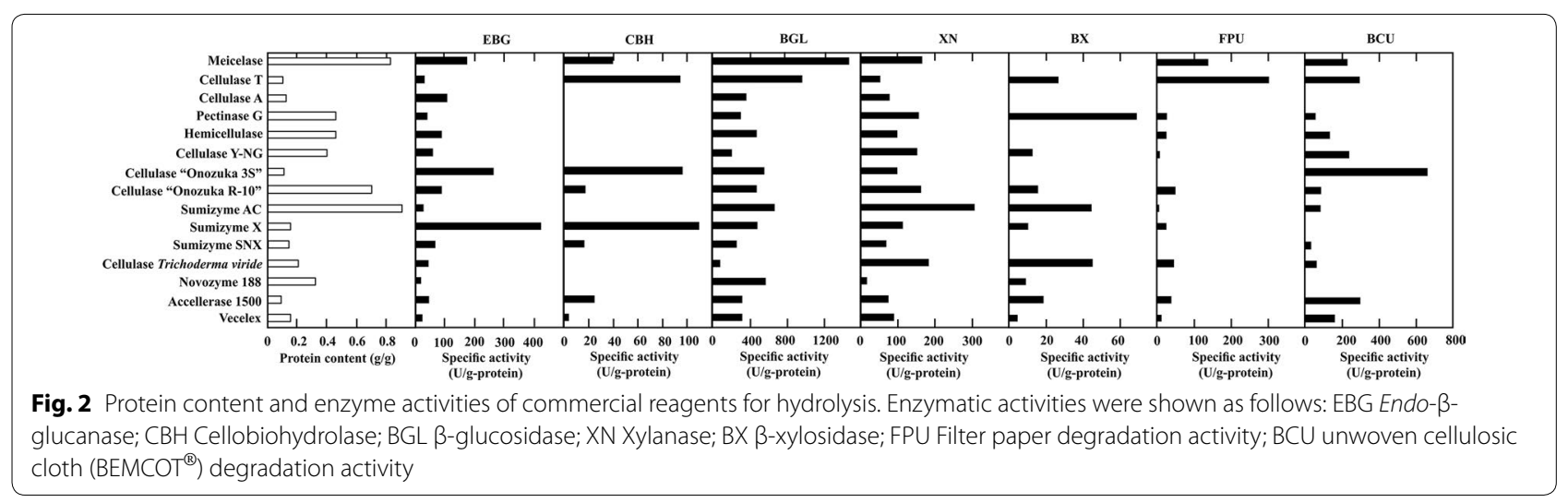




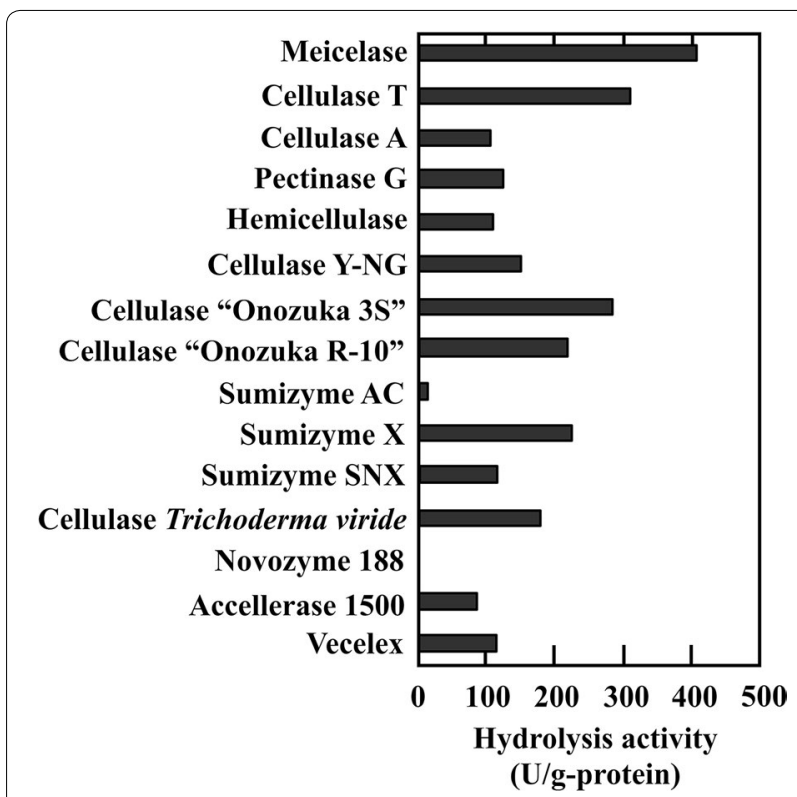

Fig. 3 Hydrolysis activities of alkali-pretreated rice straw by commercial enzyme reagents. Reaction was performed on $10 \mathrm{~g} / \mathrm{L}$ pretreated straw with each enzyme reagent of $1 \mathrm{~g}$-protein/ $\mathrm{L}$ at $\mathrm{pH} 5.5,28^{\circ} \mathrm{C}$, and $120 \mathrm{rpm}$. The activity was determined as reducing-sugar production per 1 min

of reagents will make it possible to apply the analysis and that will help selection of hydrolysis enzyme reagents.

An optimal enzyme cocktail containing selected three reagents was constructed according to DOE with RSM to efficiently biodegrade alkali-treated rice straw by enzymatic hydrolysis. Software Design Export $8^{\circledR}$ structured 14 kinds of mixture patterns of three reagents as shown in Table 1 and hydrolysis reactions of the straw with the mixture were carried out in culture medium at $\mathrm{pH} 5.5$ for $48 \mathrm{~h}$ at $28{ }^{\circ} \mathrm{C}$. Then, glucose and xylose concentrations obtained by these reactions were input and applied for ANOVA in the software. Figure 4 shows a 3D-response surface graph obtained by the calculation. The response was desirability for the production of both glucose and xylose together from the straw, and $\mathrm{A}, \mathrm{B}$, and $\mathrm{C}$ show the set range of Onozuka (1-2 g/L), Cellulase T (0-1 g/L), and Pectinase G $(0-1 \mathrm{~g} / \mathrm{L})$, respectively. Although the analysis also drew another response graphs of expected glucose and xylose each (data not shown), we adopted the desirability for effective hydrolysis to produce both of the sugars. From the analysis, an optimum ratio of cellulase cocktail was calculated by ANOVA of the response function as follows: Cellulase T:Onozuka:Pectinase $G=0.333: 0.388: 0.286$. Hydrolysis with the optimal cocktail was promised the largest amount of fermented sugar (total glucose and xylose) from alkali-treated rice straw. DOE method can propose how combine several types of reagent not only the enzymes like this study but also other parameters on medium components or culture conditions. The method will be better approach to adapt the reagents successfully by synergy of activities which affect to biomass hydrolysis, because commercial enzymes contain multiple activities due to the low purification.

\section{Fermentable sugar production from alkali-treated rice straw by three selected enzyme reagents or an optimal cocktail}

Hydrolysis effect by the optimized cocktail designed by RSM was confirmed and was compared with that of each enzyme reagent alone on the alkali-treated rice straw. The treated straw of $100 \mathrm{~g} / \mathrm{L}$ was reacted with these enzymes for $96 \mathrm{~h}$ at $\mathrm{pH} 5.5$ and $28^{\circ} \mathrm{C}$. Figure 5 shows sugars production from the straw with the each reagent or the cocktail at protein concentration of $2 \mathrm{~g} / \mathrm{L}$.

In all hydrolysis reactions of the substrate, indicated $\mathrm{pH}$ were almost constant value through the reactions. In the reaction with Cellulase $\mathrm{T}$ as shown in Fig. 5a, disaccharides, glucose, xylose, and arabinose were began to release in the early stage of the reaction and concentrations of them grew continuously for $96 \mathrm{~h}$. Glucose kept increasing and achieved $30.1 \mathrm{~g} / \mathrm{L}$ at $96 \mathrm{~h}$, which was $46 \%$ of the cellulose content in the straw. This behavior was caused by high CBH and BGL activity in Cellulase $\mathrm{T}$; that is, $\mathrm{CBH}$ in the reagent behaved for disaccharides production, and immediately, it converted to glucose by BGL activity with keeping apparent disaccharides on at low level. However, low EBG activity in the reagent caused scarce degradation of amorphous part of cellulose fiber that suppressed glucose production, though FPU activity was relatively high compared with other reagent, as shown in Fig. 2. Total concentration of glucose and xylose was $42.4 \mathrm{~g} / \mathrm{L}$ and the hydrolysis efficiency was $53 \%$ based on the total cellulose and hemicellulose content in the straw. In hydrolysis of the straw by Pectinase G, glucose and xylose could be produced without disaccharide accumulation through the reaction due to low $\mathrm{CBH}$ activity (Fig. 5b). The amount of produced glucose was $30.3 \mathrm{~g} / \mathrm{L}$ which was the same level of Cellulase T. At the same time, $12.2 \mathrm{~g} / \mathrm{L}$ of xylose was able to be produced for $96 \mathrm{~h}$ and the yield was $84.1 \%$ of hemicellulose content in the straw. That was the highest yield among the three reagents alone due to particular high $\mathrm{XN}$ and BX activity. In the hydrolysis reaction of Onozuka as shown in Fig. 5c, glucose, xylose, disaccharide, and arabinose were produced from the straw. Glucose and xylose were produced at the concentration of 45.6 and $10.0 \mathrm{~g} / \mathrm{L}$, respectively, for $96 \mathrm{~h}$. The sum concentration of these sugars was $55.7 \mathrm{~g} / \mathrm{L}$ that showed hydrolysis efficiency of $69.6 \%$. The highest 
Table 1 Design models on mixture ratio of three kinds of cellulase reagents for optimization of cocktail

\begin{tabular}{|c|c|c|c|c|c|}
\hline Run & Enzyme 1 onozuka ( $g / L)$ & Enzyme 2 cellulase $\mathrm{T}(\mathrm{g} / \mathrm{L})$ & Enzyme 3 pectinase $\mathrm{G}(\mathrm{g} / \mathrm{L})$ & Response 1 glucose (g/L) & Response 2 xylose (g/L) \\
\hline 1 & 1.833 & 0.833 & 0.333 & 25.2 & 6.54 \\
\hline 2 & 2 & 0 & 1 & 28.6 & 6.66 \\
\hline 3 & 2 & 1 & 0 & 17.4 & 6.53 \\
\hline 4 & 2 & 0 & 1 & 28.1 & 6.57 \\
\hline 5 & 1.5 & 1 & 0.5 & 27.0 & 6.97 \\
\hline 6 & 1.833 & 0.333 & 0.833 & 26.7 & 6.37 \\
\hline 7 & 2 & 1 & 0 & 17.6 & 5.84 \\
\hline 8 & 1 & 1 & 1 & 25.3 & 7.17 \\
\hline 9 & 2 & 0.5 & 0.5 & 27.7 & 6.65 \\
\hline 10 & 1.333 & 0.833 & 0.833 & 27.7 & 7.58 \\
\hline 11 & 1 & 1 & 1 & 26.1 & 7.15 \\
\hline 12 & 1.5 & 0.5 & 1 & 27.5 & 7.19 \\
\hline 13 & 1.5 & 0.5 & 1 & 27.9 & 7.40 \\
\hline 14 & 1.667 & 0.667 & 0.667 & 25.6 & 6.40 \\
\hline
\end{tabular}

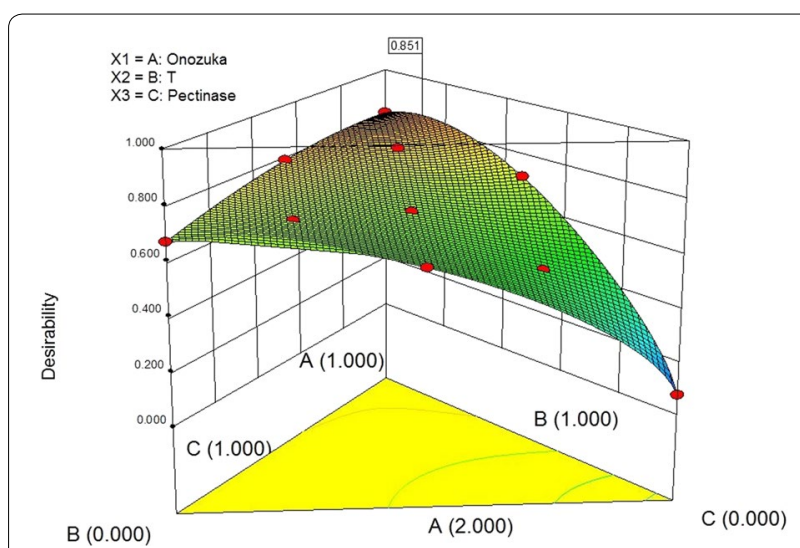

Fig. 4 Response surface of desirability of hydrolysis for optimization of mixture ratio. The mixing ratio for three enzyme reagents was calculated by central composite design method using Design-Expert $8^{\circledR}$

amount of disaccharide was produced by the reagent among the three kinds of reagents at the concentration of $15.9 \mathrm{~g} / \mathrm{L}$ for $96 \mathrm{~h}$. Disaccharide (mostly cellobiose) accumulation was caused by low BGL activity in Onozuka, whereas EBG, $\mathrm{CBH}$, and $\mathrm{BCU}$ activities were high. In fact, oligosaccharides that had various lengths were detected by HPLC analysis (not identified). Accumulated disaccharides had to be degraded to glucose and xylose for fermentation to ethanol. Meanwhile, on hydrolysis of the treated straw by the optimized cocktail as shown in Fig. 5d, higher glucose and xylose concentrations achieved at 53.2 and $13.5 \mathrm{~g} / \mathrm{L}$ than that in the reactions with three single reagents, respectively. The yields of glucose and xylose from the straw was 81.2 and $93.1 \%$, respectively. The hydrolysis efficiency on total fermentable sugars reached $83.3 \%$. These were the highest value among the four patterns of reactions and that represented the cocktail greatly affected hydrolysis of the alkali-treated straw by interaction of the three reagents. In addition, glucose production proceeded satisfactory without accumulation of disaccharides. Combination with Cellulase $\mathrm{T}$ that possesses high $\mathrm{CBH}$, BGL and FPU and Onozuka that possess high EBG, $\mathrm{CBH}$, and $\mathrm{BCU}$ was able to progress degradation of disaccharides to glucose by synergy effect of these activities each other. Particularly, BGL in Cellulase T interacted with disaccharides produced by Onozuka activity. Moreover, since disaccharides contained not only cellobiose but also xylobiose, the BX activity in Pectinase G affected the xylobiose that produced by activity in Onozuka to induce xylose production.

Combination of several enzyme reagents complemented deficient activities in these reagents each other and effective fermentable sugar production from lignocellulosic substance was successfully demonstrated using the optimized enzyme cocktail. Several studies have regarded optimization results of enzyme for fermentable sugar production by RSM (Qin et al. 2017; Zhong et al. 2009). However, these reports arbitrarily selected several enzymes based on the previous experiences or articles. The method in this study provided better approach that started from a selection method among many kinds of commercial reagents based on detailed investigation of activities and statistical examination than vague choice of them. No matter if some reagents have to be selected from more kinds of reagents than that of in this study (15 kinds), the application of the proposed method will submit appropriate response for any biomass. And then, 

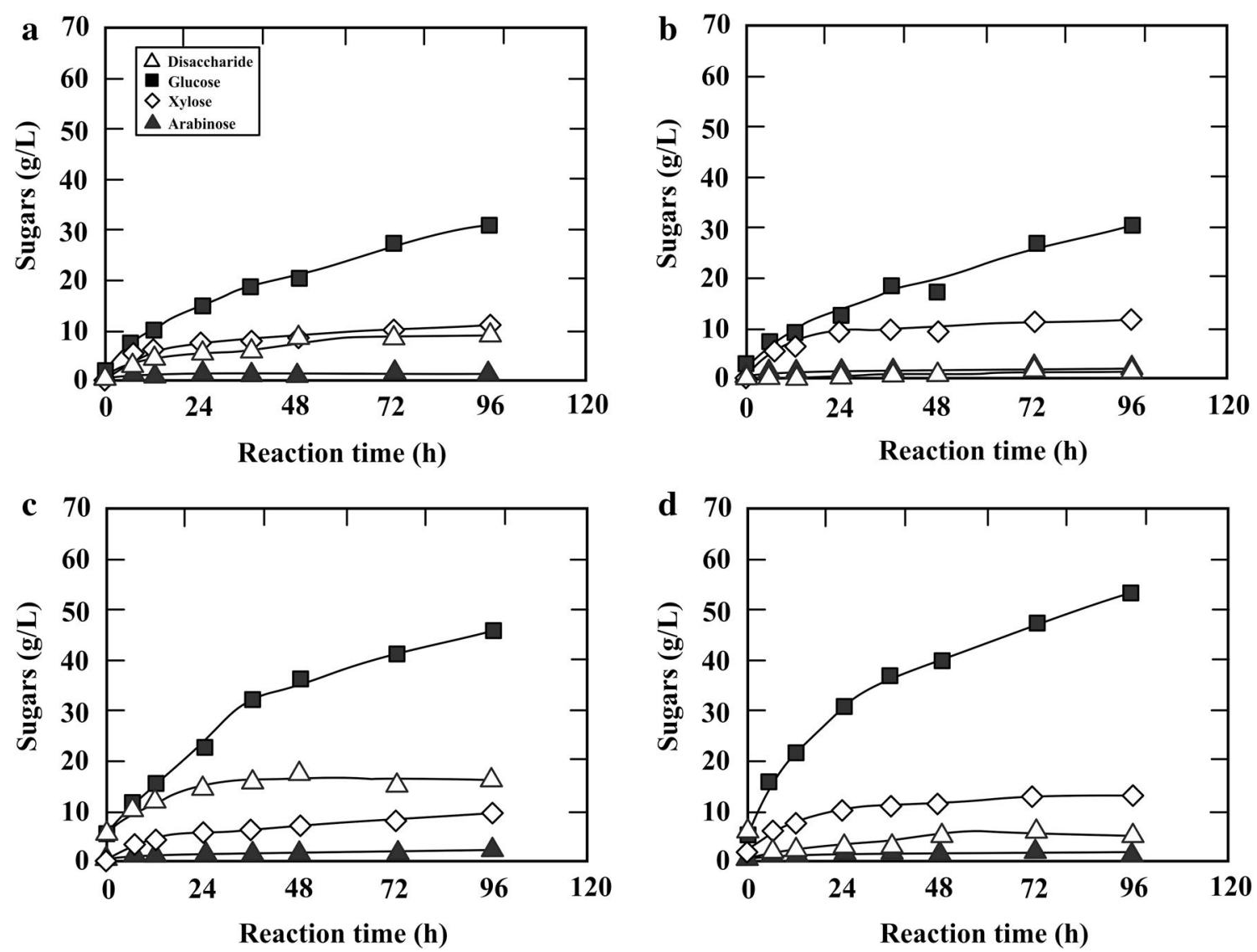

Fig. 5 Production of fermentable sugars from alkali-pretreated rice straw by enzyme reagents alone or optimized cocktail. Hydrolysis reaction was performed with $100 \mathrm{~g} / \mathrm{L}$ rice straw in culture medium at pH 5.5, $28^{\circ} \mathrm{C}$, and $120 \mathrm{rpm}$. a Cellulase T, b Pectinase G, c Onozuka, d cocktail

optimizing these enzymes by DOE will be able to induce successful hydrolysis.

\section{SSF of alkali-treated rice straw with fermentable fungus and optimized cocktail}

Ethanol production from $100 \mathrm{~g} / \mathrm{L}$ of the alkali-treated rice straw was examined by simultaneous saccharification and fermentation (SSF) with an ethanol-producing fungus, $M$. circinelloides $\mathrm{J}$, and the optimized cocktail at protein concentration of $2 \mathrm{~g} / \mathrm{L}, \mathrm{pH} 5.5$, and $28^{\circ} \mathrm{C}$ for $96 \mathrm{~h}$.

As control experiments, three SSFs were performed using three selected reagents alone. In all SSFs as shown in Fig. 6, cellulose and hemicelluloses in the straw were hydrolyzed to disaccharides, glucose, and xylose at the early stage of cultivation. Then, these were consumed by fungus and subsequently converted to ethanol by the fungus. Ethanol was started to produce after $12 \mathrm{~h}$ in all cultivations. In the SSF with Cellulase $\mathrm{T}$ as shown in Fig. 6a, 9.2 g/L glucose and $6.1 \mathrm{~g} / \mathrm{L}$ xylose appeared at the initial stage of cultivation, and then, they were consumed immediately by the fungus. Then, ethanol reached $21.8 \mathrm{~g} / \mathrm{L}$ at $48 \mathrm{~h}$ and the yield based on the fermentable sugar content in the substrate material and the productivity was $53.5 \%$ and $0.454 \mathrm{~g} / \mathrm{L} / \mathrm{h}$, respectively. Assimilation of the sugars by the fungus resolved product inhibition to enzyme caused by accumulation of them, and consequently, the sugar production in SSF was smoother than that in hydrolysis reaction without the fermenting strain. Moreover, the fungus converted oligosaccharides in the culture to ethanol directly. Because glucose production rate might be slower than fermentation rate, the fungus assimilated cellobiose, etc. before enzymatic degradation to glucose by particular fermentation ability of the strain on these sugars. In the SSF with Pectinase $G$ as shown Fig. $6 \mathrm{~b}, 6.5 \mathrm{~g} / \mathrm{L}$ glucose and $6.9 \mathrm{~g} / \mathrm{L}$ xylose were produced for $12 \mathrm{~h}$, and then, these sugars consumed with fermentation by the fungus to produce $12.3 \mathrm{~g} / \mathrm{L}$ ethanol for $48 \mathrm{~h}$. The produced ethanol was lower than that of SSF with Cellulase $\mathrm{T}$, whereas hydrolysis efficiency was the same level, as shown in Fig. 5. Because Pectinase $G$ possesses scanty degrading activity to the straw such as FPU, the rate of fermentable sugar supply from the straw was not enough to produce high ethanol, even though product inhibition was resolved by the fungus. When Onozuka 
was used for SSF as shown in Fig. 6c, $13.6 \mathrm{~g} / \mathrm{L}$ glucose and $9.7 \mathrm{~g} / \mathrm{L}$ disaccharides were produced quickly in the early stage of the culture and the subsequent fermentation produced ethanol of $28.9 \mathrm{~g} / \mathrm{L}$ for $48 \mathrm{~h}$. The yield and productivity were $70.7 \%$ and $0.602 \mathrm{~g} / \mathrm{L} / \mathrm{h}$, respectively. About $4.0 \mathrm{~g} / \mathrm{L}$ xylose was produced and the sugar existed in the culture through the SSF, because diauxie effect suppressed the fungus fermenting of xylose under the presence of comfortable glucose. Moreover, appeared disaccharides at the early stage of SSF were decreased quickly for $24 \mathrm{~h}$. Secretion of BGL and assimilation of disaccharides by the fungus helped the utilization of produced them for fermentation, whereas the sugars accumulated in hydrolysis reaction bottle, as shown in Fig. 5c.

Yet, on the SSF with the optimized enzymes cocktail, as shown in Fig. 6 d, the highest glucose and xylose was able to be produced at the concentration of 18.4 and $8.0 \mathrm{~g} / \mathrm{L}$ without disaccharides accumulation, respectively. In addition, subsequently, $30.6 \mathrm{~g} / \mathrm{L}$ ethanol was able to be produced effectively for $36 \mathrm{~h}$. The productivity and the fermentation efficiency achieved the highest value of $0.85 \mathrm{~g} / \mathrm{L} / \mathrm{h}$ and $90.0 \%$ of hydrolyzed fermentable sugar basis, respectively. The yield that cellulose content basis in the treated straw achieved $91.4 \%$. Synergistic effect led to efficient production of glucose and xylose by Cellulase $\mathrm{T}$ that including high $\mathrm{CBH}, \mathrm{BGL}$ and FPU, Onozuka that including high $\mathrm{EBG}, \mathrm{CBH}$, and $\mathrm{BCU}$, and Pectinase $\mathrm{G}$ including $\mathrm{XN}$ and $\mathrm{BX}$. Although disaccharides were produced from the straw by $\mathrm{CBH}$ and other cellulase activities in Onozuka, BGL in Cellulase $\mathrm{T}$ and that secreted by the fungus could degraded them to glucose as soon as produced. Moreover, a few of them appeared in the culture were also assimilated by the fungus. These advantages induced the highest ethanol production compared to SSF with each reagent alone. Since the optimized cocktail improved hydrolysis from the estimation with three reagents alone, the hydrolysis rate was faster comfortable for ethanol production rate. Moreover, resolution of product inhibition also increased the hydrolysis rate and that induced high ethanol production. In addition, a

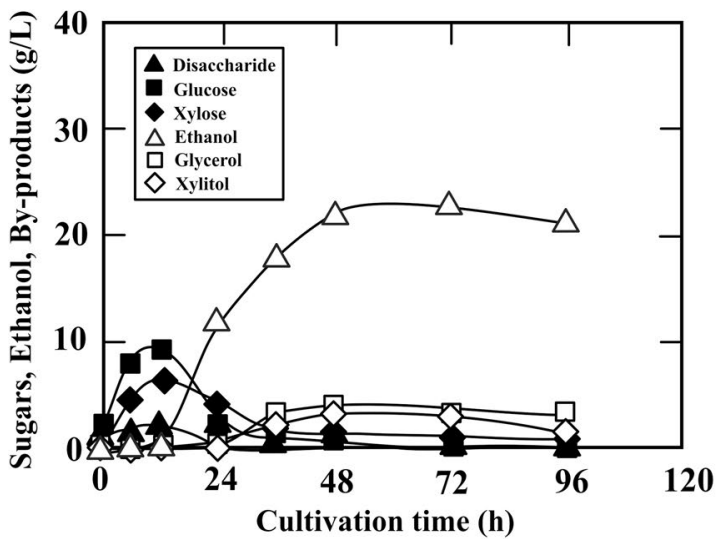

c

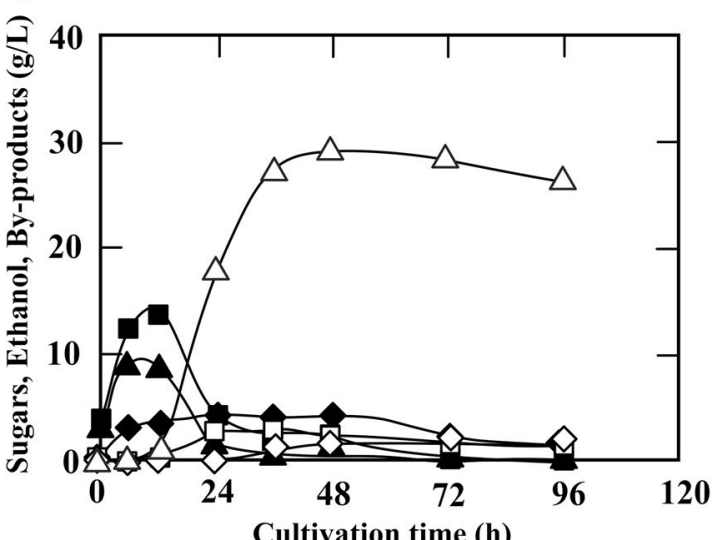

b

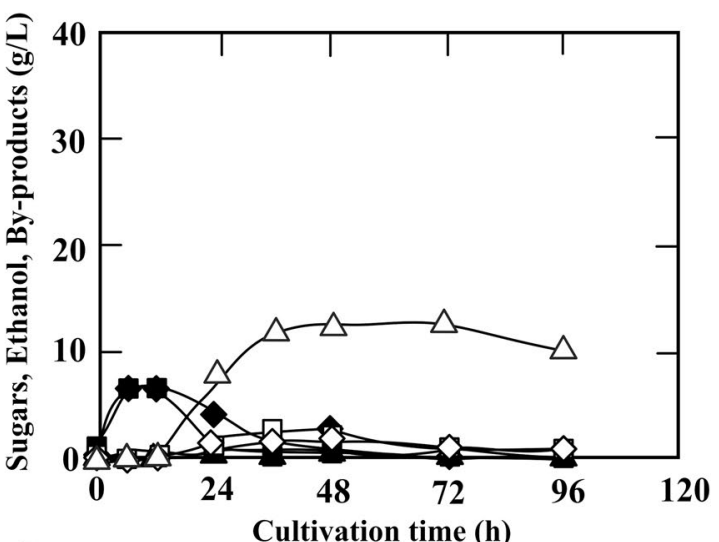

d

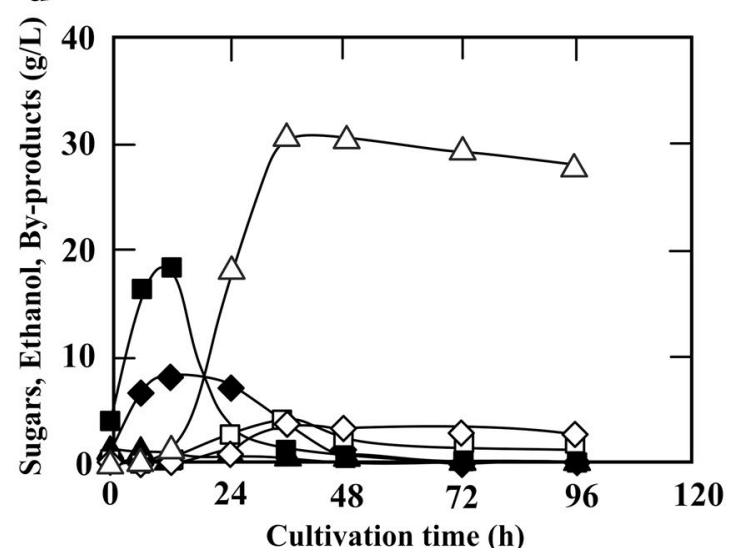

Fig. 6 Ethanol production by M. circinelloides J by SSF of alkali-pretreated rice straw. The used enzymes were the selected reagents alone or optimized cellulase cocktail. Cultivation was performed at $\mathrm{pH} 5.5,28^{\circ} \mathrm{C}$, and $120 \mathrm{rpm}$. a Cellulase T, b Pectinase G, c Onozuka, d: cocktail 
by-products such as xylitol in the SSF were barely formed from xylose metabolism, because the highest xylose was produced by the cocktail from the straw, which was not used for ethanol production. At the same time, the SSFs decreased $\mathrm{pHs}$ from 5.5 to 3.2-4.3, and the lower $\mathrm{pH}$ was, the higher ethanol was produced. The secretion of various substances by the fungus with growth should decrease the $\mathrm{pHs}$. Since optimum $\mathrm{pH}$ of general cellulases is mild acidity about $3-4$, the lower $\mathrm{pH}$ could activate hydrolysis reactions for the rice straw degradation by enzyme reagents. More fermentable sugars were released under low $\mathrm{pH}$ condition in the medium from the straw by efficient hydrolysis with the cocktail, and the more fungus was able to grow and to produce ethanol.

The proposed SSF system with the optimized cellulase cocktail and the novel ethanol-producing fungus is a promising method that was able to produce bioethanol directly from not only rice straw but also other lignocellulosic biomass. To utilize all sugars existing in rice straw, improvement of SSF system must be investigated about cultivation conditions: enzyme dose, medium composition, $\mathrm{pH}$, temperature, surfactants addition, and aeration. For example, high temperature can improve hydrolysis reaction more quickly than low temperature because that activates these enzymes at $40-60{ }^{\circ} \mathrm{C}$. However, the fungus can grow only in mild condition like room temperature. Construction of high-performing strain that can tolerate high temperature will achieve more effective SSF.

\section{Comparison of SSF from several pretreated rice straws by various strains}

Rice straw is one of the desirable biomass as good feedstock of ethanol production and has been investigated by combining several treatments and fermenting microorganisms. Table 2 shows the comparison of various SSFs using pretreated rice straws under close conditions to this study. All conditions were related in ethanol production strongly. Various enzyme reagents were used for each report and these performed well on hydrolysis of these substrates. However, it was doubtful whether these were really suitable for the substrates, because many amount of dose can achieve high degradation of biomass even if enzyme was not match to the substrates. We suggested effective selection and optimization methods to resolve that matter, which induced effective SSF with low dose of the reagents. As shown in Table 2, alkali pretreatment of rice straw led to higher ethanol productions and that yields comparatively than acid treatment. Particularly, these yields were significantly higher than that of acid treatment processes. Since alkali treatment can break crystal structure and soften the fiber, the advantage induced good hydrolysis and subsequent fermentation. Our study reported the highest ethanol production and yield among these reports, because optimization of enzyme mixture affected highly to hydrolysis of the straw. In addition, it was reason that the fungus used in this study could convert not only glucose and xylose to ethanol, but also secret slightly several cellulases which

Table 2 Comparison of SSF of several pretreated rice straws by various strains

\begin{tabular}{|c|c|c|c|c|c|c|c|c|}
\hline Treatment & Cellulase & Strain & $\begin{array}{l}\text { Maximum ethanol } \\
\text { concentration } \\
(\mathrm{g} / \mathrm{L})\end{array}$ & $\begin{array}{l}\text { Yield of cellu- } \\
\text { lose basis (\%) }\end{array}$ & $\begin{array}{l}\text { Productivity } \\
\text { (g/L/h) }\end{array}$ & $\begin{array}{l}\text { Temperature } \\
\left({ }^{\circ} \mathrm{C}\right)\end{array}$ & $\mathrm{pH}$ & References \\
\hline \multirow[t]{3}{*}{$\mathrm{H}_{2} \mathrm{SO}_{4}$} & BTLX & $\begin{array}{c}\text { Saccharomyces } \\
\text { cerevisiae }\end{array}$ & 6.83 & 40.7 & 0.284 & 38 & 5.0 & $\begin{array}{l}\text { Karimi et al. } \\
\text { (2006) }\end{array}$ \\
\hline & & Mucorindicus & 7.79 & 46.4 & 0.649 & 38 & 5.5 & \\
\hline & & Rhizopus oryzae & 9.2 & 54.8 & 0.383 & 38 & 5.5 & \\
\hline $\mathrm{NH}_{3}$ & $\begin{array}{l}\text { Celluclast } 1.5 \mathrm{~L} \\
\text { Accellerase } 1500 \\
\text { Novozyme } 188 \\
\text { Xylanase }\end{array}$ & S.cerevisiae & 12.7 & 83.1 & 0.250 & 38 & 4.8 & Ko et al. (2009) \\
\hline $\begin{array}{c}\mathrm{H}_{2} \mathrm{SO}_{4} \text { and } \\
\mathrm{NaOH}\end{array}$ & $\begin{array}{l}\text { Crude cellulase from } \\
\text { Aspergillus and } \\
\text { Trichoderma }\end{array}$ & Kluveromyces sp. & 23.2 & 51.3 & 0.386 & 42 & 4.8 & Narra et al. (2015) \\
\hline $\mathrm{NaOH}$ & Accellerase 1000 & $\begin{array}{l}\text { S. cerevisiae and } \\
\text { Scheffersomy- } \\
\text { ces stipitis }\end{array}$ & 28.6 & 86 & 0.777 & 38 & 5.0 & $\begin{array}{l}\text { Suriyachai et al. } \\
\text { (2013) }\end{array}$ \\
\hline $\mathrm{NaOH}$ & $\begin{array}{l}\text { Celluclast } 1.5 \mathrm{~L} \\
\text { Novozyme } 188 \\
\text { Pectinase }\end{array}$ & $\begin{array}{l}\text { Pichia kudri- } \\
\text { avzevii }\end{array}$ & 24.3 & 82 & 1.01 & 40 & 4.0 & $\begin{array}{l}\text { Oberoi et al. } \\
\text { (2012) }\end{array}$ \\
\hline $\mathrm{NaOH}$ & $\begin{array}{l}\text { Cellulase T } \\
\text { Cellulase Onozuka } \\
35 \\
\text { Pectinase }\end{array}$ & M. circinelloides & 30.6 & 91.4 & 0.850 & 28 & 5.5 & This study \\
\hline
\end{tabular}


helped fermentable sugar production. Productivities were relatively high on SSF with Mucor fungi from the results of these reports. Although yeast of Saccharomyces sp. used general ethanol production, the fungi are also favorable microorganism on fermenting and enzymes secreting ability in the process of biomass conversion. In all SSFs, appropriate $\mathrm{pH}$ for fermenting microorganisms was used; that is, yeast was cultured in $\mathrm{pH} 4-5$ and fungi in $\mathrm{pH}$ 5.5. The cultivation temperature is an important factor which strongly affects both hydrolysis by enzyme and fermentation by microbes, since generally hydrolysis ability of enzymes can be improved with increasing of reaction temperature. Although the optimal temperature of cellulase is generally around $50^{\circ} \mathrm{C}$, most researches on SSF was performed less than $40^{\circ} \mathrm{C}$, as shown in Table 2, because general fermenting strains cannot grow at the temperature. Therefore, the creation of novel fermenting microorganism, which has endurance for high temperature around $50{ }^{\circ} \mathrm{C}$, is expected to be lead to the development of more efficient bioethanol production process than that of present study.

\section{Conclusion}

This study was presented a promising process for decision of enzyme reagents for hydrolysis of alkali-pretreated rice straw by statistical approach and efficient ethanol production by SSF. The pretreatment method of alkali $(\mathrm{NaOH})$ with heating resulted in effective lignin removal from raw rice straw and making a high sugar content material. Multivariate analysis could suggest several required enzymatic activities and derive a selection of appropriate reagents for the pretreated rice straw. Three kinds of desired reagents were selected from 15 kinds of commercial enzyme reagents based on the analysis. DOE with RSM proposed an optimum ratio of enzyme cocktail consisted of the three reagents for effective production of fermentable sugar from the alkali-treated straw. The enzyme cocktail constructed by these statistical approaches advanced hydrolysis efficiency to $83.3 \%$ at $2 \mathrm{~g}$-protein/L from low efficiencies with each reagent alone. SSF of the alkali-treated straw using a novel pentose-fermenting fungus with the cocktail achieved high ethanol production with the fermenting efficiency of $90 \%$ of fermentable sugar basis. Further investigations suggest enhancement of ethanol production from lignocellulosic biomass by any improvement such as increase of temperature.

\section{Authors' contributions}

TM carried out all experiments and analysis and prepared the manuscript. HK contributed reagents, materials, and analysis tools. HK reviewed the results, helped data analysis, and edited the manuscript. HK has given final approval of the version to be published. Both authors read and approved the final manuscript.
Authors' information

TM is Research Assistant belonged to Graduate School of Science and Engineering, University of Toyama. HK is Associate Professor belonged to Graduate School of Science and Engineering, University of Toyama.

\section{Acknowledgements}

Not applicable.

\section{Competing interests}

The authors declare that they have no competing interests.

\section{Availability of data and materials}

The data set (graphs and tables) supporting the conclusions of this article is available.

\section{Consent for publication}

All authors have read and approved to submit it to Bioresources and Bioprocessing. There is no conflict of interest of any author in relation with the submission.

\section{Ethics approval and consent to participate}

Not applicable.

\section{Funding}

This study was financially supported by High Efficiency Bioenergy Conversion Project of New Energy and Industrial Technology Development Organization (NEDO) in Japan.

\section{Publisher's Note}

Springer Nature remains neutral with regard to jurisdictional claims in published maps and institutional affiliations.

Received: 5 January 2018 Accepted: 29 March 2018

Published online: 04 April 2018

\section{References}

Binod P, Sindhu R, Singhania RR, Vikram S, Devi L, Nagalakshmi S, Kurien $\mathrm{N}$, Sukumaran RK, Pandey A (2010) Bioethanol production from rice straw: an overview. Bioresour Technol 101(13):4767-4774. https://doi. org/10.1016/j.biortech.2009.10.079

Breuil C, Saddler JN (1985) Comparison of the 3,5-dinitrosalicylic acid and Nelson-Somogyi methods of assaying for reducing sugars and determining cellulase activity. Enzyme Microb Technol 7:327-332. https://doi. org/10.1016/0141-0229(85)90111-5

Carvalheiro F, Duarte LC, Gírio FM (2008) Hemicellulose biorefineries: a review on biomass pretreatments. J Sci Ind Res 67:849-864. https://doi. org/10.1016/.talanta.2015.06.045

Chandra R, Takeuchi H, Hasegawa T, Kumar R (2012) Improving biodegradability and biogas production of wheat straw substrates using sodium hydroxide and hydrothermal pretreatments. Energy 43:273-282. https:// doi.org/10.1016/j.energy.2012.04.029

Gáspár M, Kálmán G, Réczey K (2007) Corn fiber as a raw material for hemicellulose and ethanol production. Process Biochem 42:1135-1139. https:// doi.org/10.1016/j.procbio.2007.04.003

Inokuma K, Takano M, Hoshino K (2013) Direct ethanol production from $\mathrm{N}$-acetylglucosamine and chitin substrates by Mucor species. Biochem Eng J 72:24-32. https://doi.org/10.1016/j.bej.2012.12.009

Janker-Obermeier I, Sieber V, Faulstich M, Schieder D (2012) Solubilization of hemicellulose and lignin from wheat straw through microwave-assisted alkali treatment. Ind Crops Prod 39:198-203. https://doi.org/10.1016/j. indcrop.2012.02.022

Jin S, Chen H (2006) Superfine grinding of steam-exploded rice straw and its enzymatic hydrolysis. Biochem Eng J 30:225-230. https://doi. org/10.1016/j.bej.2006.05.002

Karimi K, Emtiazi G, Taherzadeh MJ (2006) Ethanol production from dilute-acid pretreated rice straw by simultaneous saccharification and fermentation 
with Mucor indicus, Rhizopus oryzae, and Saccharomyces cerevisiae. Enzyme Microb Technol 40:138-144

Kato Y, Nomura T, Ogita S, Takano M, Hoshino K (2013) Two new $\beta$-glucosidases from ethanol-fermenting fungus Mucor circinelloides NBRC 4572: enzyme purification, functional characterization, and molecular cloning of the gene. Appl Microbiol Biotechnol 97:10045-10056. https://doi. org/10.1007/s00253-013-5210-5

Khaleghian H, Karimi K, Behzad T (2015) Ethanol production from rice straw by sodium carbonate pretreatment and Mucor hiemalis fermentation. Ind Crops Prod 76:1079-1085. https://doi.org/10.1016/j.indcrop.2015.08.008

Kim TH, Lee YY (2007) Pretreatment of corn stover by soaking in aqueous ammonia at moderate temperatures. Appl Biochem Biotechnol 137-140:81-92. https://doi.org/10.1007/s12010-007-9041-7

Ko JK, Bak JS, Jung MW, Lee HJ, Choi IG, Kim TH, Kim KH (2009) Ethanol production from rice straw using optimized aqueous-ammonia soaking pretreatment and simultaneous saccharification and fermentation processes. Bioresour Technol 100:4374-4380

Komeda H, Yamasaki-Yashiki S, Hoshino K, Asano Y (2014) Identification and characterization of D-xylulokinase from the $\mathrm{D}$-xylose-fermenting fungus, Mucor circinelloides. FEMS Microbiol Lett 360:51-61. https://doi. org/10.1111/1574-6968.12589

Liu Z-H, Qin L, Zhu J-Q, Li B-Z, Yuan Y-J (2014) Simultaneous saccharification and fermentation of steam-exploded corn stover at high glucan loading and high temperature. Biotechnol Biofuels 7:167. https://doi.org/10.1186/ s13068-014-0167-X

López M, Huerta-Pujol O, Martínez-Farré FX, Soliva M (2010) Approaching compost stability from Klason lignin modified method: chemical stability degree for OM and N quality assessment. Resour Conserv Recycl 55:171-181. https://doi.org/10.1016/j.resconrec.2010.09.005

Lowry OH, Rosebrough NJ, Lewis Farr A, Randall RJ (1951) Protein measurement with the folin phenol reagent. J Biol Chem 193:265-275. https://doi. org/10.1016/0304-3894(92)87011-4

Marx S, Ndaba B, Chiyanzu I, Schabort C (2014) Fuel ethanol production from sweet sorghum bagasse using microwave irradiation. Biomass Bioenerg 65:145-150. https://doi.org/10.1016/j.biombioe.2013.11.019

Millati R, Edebo L, Taherzadeh MJ (2005) Performance of Rhizopus, Rhizomucor, and Mucor in ethanol production from glucose, xylose, and wood hydrolyzates. Enzyme Microb Technol 36:294-300. https://doi.org/10.1016/j. enzmictec.2004.09.007

Nair RB, Kalif M, Ferreira JA, Taherzadeh MJ, Lennartsson PR (2017) Mildtemperature dilute acid pretreatment for integration of first and second generation ethanol processes. Bioresour Technol 245:145-151. https:// doi.org/10.1016/j.biortech.2017.08.125
Narra M, James JP, Balasubramanian V (2015) Simultaneous saccharification and fermentation of delignified lignocellulosic biomass at high solid loadings by a newly isolated thermotolerant Kluyveromyces sp. for ethanol production. Bioresour Technol 179:331-338

Oberoi HS, Babbar N, Sandhu SK, Dhaliwal SS, Kaur U, Chadha BS, Bhargav VK (2012) Ethanol production from alkali-treated rice straw via simultaneous saccharification and fermentation using newly isolated thermotolerant Pichia kudriavzevii HOP-1. J Ind Microbiol Biotechnol 39:557-566

Qin L, Li X, Zhu JQ et al (2017) Optimization of ethylenediamine pretreatment and enzymatic hydrolysis to produce fermentable sugars from corn stover. Ind Crops Prod 102:51-57. https://doi.org/10.1016/j. indcrop.2017.03.026

Sasaki C, Sumimoto K, Asada C, Nakamura Y (2012) Direct hydrolysis of cellulose to glucose using ultra-high temperature and pressure steam explosion. Carbohydr Polym 89:298-301. https://doi.org/10.1016/j. carbpol.2012.02.040

Singh A, Bishnoi NR (2012) Enzymatic hydrolysis optimization of microwave alkali pretreated wheat straw and ethanol production by yeast. Bioresour Technol 108:94-101. https://doi.org/10.1016/j.biortech.2011.12.084

Suriyachai N, Weerasaia K, Laosiripojana N, Champreda V, Unrean P (2013) Optimized simultaneous saccharification and co-fermentation of rice straw for ethanol production by Saccharomyces cerevisiae and Scheffersomyces stipitis co-culture using design of experiments. Bioresour Technol 142:171-178

Taherzadeh MJ, Karimi K (2008) Pretreatment of lignocellulosic wastes to improve ethanol and biogas production: a review. Int J Mol Sci 9:16211651. https://doi.org/10.3390/ijms9091621

Takano M, Hoshino K (2012) Direct ethanol production from rice straw by coculture with two high-performing fungi. Front Chem Sci Eng 6:139-145. https://doi.org/10.1007/s11705-012-1281-6

Wang L, Yang M, Fan X, Zhu X, Xu T, Yuan Q (2011) An environmentally friendly and efficient method for xylitol bioconversion with high-temperaturesteaming corncob hydrolysate by adapted Candida tropicalis. Process Biochem 46:1619-1626

Zhong C, Lau MW, Balan V et al (2009) Optimization of enzymatic hydrolysis and ethanol fermentation from AFEX-treated rice straw. Appl Microbiol Biotechnol 84:667-676. https://doi.org/10.1007/s00253-009-2001-0

\section{Submit your manuscript to a SpringerOpen ${ }^{\circ}$ journal and benefit from:}

- Convenient online submission

- Rigorous peer review

- Open access: articles freely available online

- High visibility within the field

- Retaining the copyright to your article

Submit your next manuscript at $\boldsymbol{\nabla}$ springeropen.com 